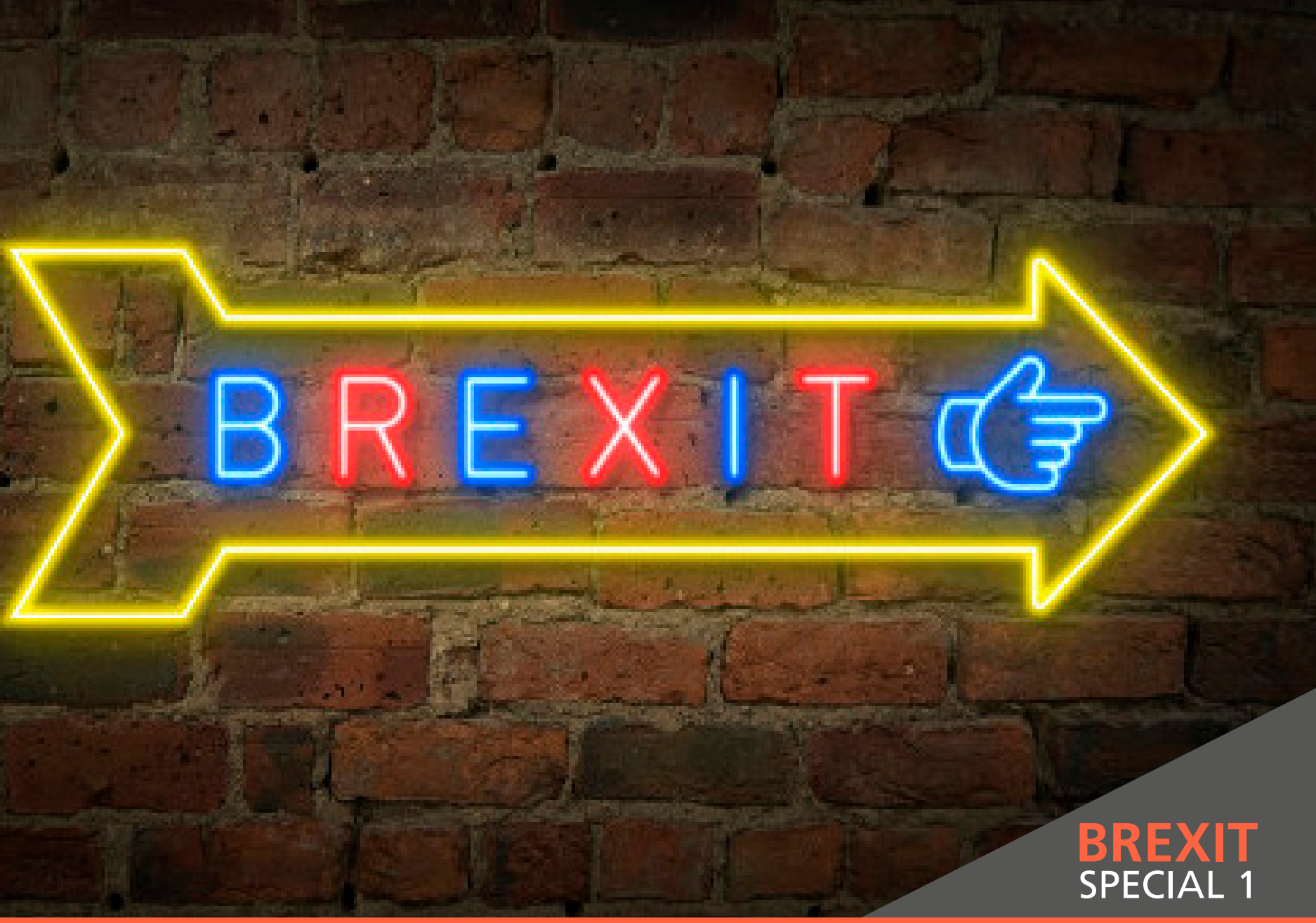

\title{
Negotiating Brexit
}

Dr. Floris de Witte 


\section{Negotiating Brexit}

The discussions on Brexit so far have mainly focused on its domestic legal implications, and its possible political consequences for both the EU and the UK. As Article 50 TEU is triggered, however, and the process of negotiating Brexit and a new deal between the UK and the EU has started, the focus shifts to the details of EU law. EU law suggests significant constraints to the renegotiation process.

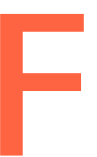

irst, EU law indicates that Brexit does not require one but two different agreements between the UK and the EU: one that defines the terms of the separation, and one that builds a new 'relationship' between the EU and the UK. While these agreements will probably be negotiated simultaneously, they are governed by different legal rules. Second, EU law suggests that while the separation agreement is limited substantively, and can be passed with a qualified majority of Member States agreeing; any new deal between the EU and the UK will be dependent on the agreement of all Member States, and all national parliaments. This makes the negotiation of a new deal a political minefield.

\section{Separation settlement}

Article 50 TEU sets out the procedure for a Member State's withdrawal from the EU. It does not, contrary to most suggestions by politicians and the media, set out the procedure or conditions for a 'new deal' between the UK and the EU. The conditions set out by Article 50 TEU relate to the conditions under which the UK will leave the EU. This separation agreement will cover the outstanding rights, obligations and liabilities that the two parties have vis-à-vis each other. These include, for example, the UK's liabilities for EU infrastructure, the capital invested in the European Investment Bank, or the pension costs for UK nationals that (have) worked for the EU institutions. More detailed studies indicate that this 'Brexit Bill' could amount to a maximum of $€ 60 \mathrm{bn}$. At the same time, the UK's share of the EU's assets is thought to amount to $€ 20 \mathrm{bn}$. Crucially, the final amount of the Brexit Bill is likely to reflect the strength of the parties' negotiation position rather than an accountant's view of the precise liabilities and assets.

A second crucial element to be discussed in the separation agreement is the acquired rights of EU citizens in the UK; and of the UK's citizens residing in the EU. These discussions will touch on a range of rights: the rights of residence for workers, the rights of residence for economically inactive residents, such as family members of workers, children, pensioners or (temporarily) unemployed citizens; but also their rights to continuous access to welfare benefits. These questions appear to be central for both the EU and the UK - both of which have indicated their desire to settle the rights of residents as soon as possible. At the same time, any agreement will probably require a blanket decision of the rights of EU/UK migrants: it appears impossible to agree on, and administer, a model that differentiates in the continuous right to residence based on length of residence, economic activity, or degree of integration of the migrant in the host state. The most likely outcome, at this point, would be a guaranteed right to residence for all UKJ EU citizens who were lawfully resident in the EU/UK on the 23th of June 2016. This might be seen as a defeat for the UK's government (given that one of the promises made in the aftermath of Brexit was to decrease migration from the EU, and not to create a scheme of indefinite residence for EU nationals that is more generous than under EU law itself), but will be relatively easy to administer. The more complex question is the extent to which these groups of already resident migrants retain their right to equal access to welfare benefits in the host state. This appears a particularly salient point for the UK pensioners in Spain and Portugal, and is a question in which the UK government might soon find itself between a rock and a hard place. On the one hand, it has read the Brexit mandate to mean to decrease immigration and be tougher on welfare payouts to migrants. On the other hand, however, the only administratively feasible solution may be to grant full equal treatment to those migrants that have obtained indefinite leave to remain. Either way, expect much political contestation and litigation.

No doubt other outstanding rights, obligations, and liabilities will be discussed in the upcoming months within the context of this separation agreement. In institutional terms, Article 50 TEU sets out clearly that, from the EU side, any deal (negotiated by the Commission) must be signed off by a qualified majority in Council (representing $55 \%$ of Member States and $65 \%$ of EU citizens), after having obtained the consent of the European Parliament. Even if the substance and procedure in this settlement agreement are complex, it can be expected that the EU and the UK agree on a deal before the two-year period specified in Article 50 TEU expires.

\section{A "New Deal" between the UK and the EU}

The 'bold and ambitious' new free trade deal that Theresa May wants to agree with the EU will not be agreed within the context of the separation agreement, even if they might be negotiated simultaneously. The new deal will be an international agreement conducted between the EU and a third state - not dissimilar to the deals that the EU has with Switzerland, Singapore, or Canada. The importance of reaching a new deal with the EU by the March 2019 is evident: by that date all existing agreements based on the EU treaties will expire, and all rights and obligations between the parties will expire. This is the 'cliff edge' that the UK is so concerned about. If we look at the legal 
rules setting out the procedure for this new deal, however, we quickly realize that it will be incredibly hard to find an agreement within two years.

First, the rules on who gets to vote on the new deal on the EU's side need to be clarified. Theresa May's Brexit speech (and the White Paper) set out a number of areas in which she wants to come to agreement with the EU: maintain an open border between Ireland and Northern Ireland, a comprehensive trade deal between the UK and the EU, access for financial services to the EU's single market, cooperation in European Research Council, European Space Agency and the combat of crime and terrorism. The problem with this is that some of these areas fall within the competences that the EU shares with its Member States, making it a so-called 'mixed agreement', which, in turn, requires all Member States and all national parliaments (in addition to the European Parliament) to sign off on it. As we have recently seen in the ratification of the free trade agreement with Canada, this means that every Member State (or even some regional parliaments) effectively has a veto over the agreement. This is even without considering that any new deal may require a referendum in Member States, such as the Netherlands or Ireland, which allow for the possibility to call referendums on the ratification of international agreements. Rather than negotiating a 'new deal' with the Commission, then, the UK will indirectly be negotiating with 28 (if not more) veto players.

This raises a second point that complicates negotiations on a new deal between the UK and the EU. A good example of this is a recent letter sent by Lodewijk Asscher, the leader of the Dutch centre-left party, sent to all centre-left leaders across the EU. In it, he suggests that Member States should not agree on any deal with the UK that does not come with strict tax avoidance rules for the future, which May and Hammond have threatened to do. The point is not that Lodewijk Asscher, who is unlike to remain in power throughout the Brexit process, will block any new deal between the UK and the EU. The point is that the voting rules for any new deal allow for individual Member States to make very specific and particular demands on the UK, which it may have to accept in order to secure its desired new deal with the EU. Those Member State demands may not even have anything to do with Brexit. It is perhaps not plausible, but completely possible, that Tsipras demands debt relief before signing an agreement, or that France demands that the UK house a number of refugees, Belgium pushes for the imposition of fishing quotas on the UK even after Brexit, and so on. To put it as simple as possible: any new deal will come with significant commitments and limitations to the UK's sovereign autonomy; and the UK is ill-placed to resist such demands given the rule that requires unanimous ratification by all Member States and their parliaments before any new deal enters into force.

A third point that requires our attention is the way in which any new deal will be institutionalized and enforced. The UK government, in its White Paper, paid close attention to different models and mechanism of dispute resolution. The explicit objective is to prevent any legal force emanating from Luxembourg, and to prevent the European Court of Justice from imposing its rulings on the UK. This creates a serious legal problem. In a number of opinions, the European Court of Justice has invalidated the EU's participation to international agreements that affect the European Court of Justice's monopoly on the final interpretation of EU law rules. To put it simply, allowing any institution other than the European Court of Justice to interpret EU law rules without supervision from Luxembourg is illegal under EU law. This means, for the Brexit discussion, that new dispute resolution bodies may be created to govern new policy agreements between the UK and the EU, but not to govern the ones that already exist under EU law, such as far-reaching commitments in police and terrorism cooperation, rules on the external borders of the EU (such as in Ireland), rules on financial services and the rules governing access to, and conditions of competition on, the internal market. This creates a significant legal problem for the UK's desire to sideline the European Court of Justice, which cannot even be circumvented with agreement of the Commission, European Parliament, and 27 Member States and their national parliaments.
The rules on voting for a new 'bold and ambitious' trade deal between the UK and the EU indicate that the power very much lies in the camp of the EU. These negotiations take place with a cliff-edge of March 2019 lurking in the background, and pit the UK against (at least) 28 veto players, all of which have different and possibly incompatible interests in the process of negotiation. It appears all but impossible to negotiate a meaningful deal within the two years set out for its agreement.

\section{Conclusion}

Now that Article 50 TEU has been triggered by the UK government, the attention shifts to the conditions under which the separation agreement and the new trade deal governing the relationship between the UK and the EU will be negotiated. Before even looking at the substantive decisions that need to be made, it is clear that the legal rules that govern the agreement between the EU and a third state make the position of the UK very complicated. All Member States and their national (or even regional) parliaments have a veto over the new deal, in addition to the European Parliament, which will require the UK to be sensitive to very disparate and far-reaching demands from its European partners. 


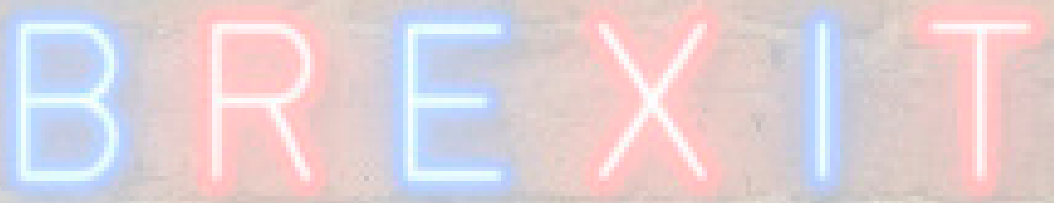

\section{FLORIS DE WITTE}

Floris de Witte is Assistant Professor at the LSE. His research deals with the interaction between EU law and political theory, with particular emphasis on free movement, the Euro-crisis and the role of the individual in the EU. Floris holds a PhD from London School of Economics and Political Science. He is co-editor of LSE Law Policy Briefing Papers and an affiliated member of the LSE European Institute.

THE LONDON SCHOOL

OF ECONOMICS AND POLITICAL SCIENCE

\section{Department of Law}

The London School of Economics

and Political Science

Houghton Street

London WC2A 2AE 